\title{
RANCANG BANGUN PROTOTIPE GARDU PEMBANGKIT LISTRIK HYBRID MIKRO HIDRO DAN SEL SURYA SEBAGAI MEDIA PEMBELAJARAN PRAKTIKUM TEKNIK ELEKTRO
}

\author{
Sugeng $^{1 *}$, Taufiqur Rokhman ${ }^{2}$, Paridawati $^{3}$, Agus Sofwan $^{4}$ \\ 1,2,3Program Studi Teknik Elektro, Universitas Islam 45 Bekasi, Bekasi, Indonesia \\ ${ }^{4}$ Program Studi Teknik Listrik, ISTN Jakarta, Jakarta, Indonesia \\ *Email: sugeng_pratama@yahoo.co.id
}

\begin{abstract}
Abstrak
Di Jurusan Teknik Elektro Universitas Islam "45" Bekasi belum mempunyai laboratorium energi terbarukan yang sangat diperlukan dalam pembelajaran praktikum energi terbarukan. Penelitian ini dirancang dan dibuat sebuah pembangkit listrik hybrid gabungan antara Pembangkit Listrik Tenaga Air dan Pembangkit Listrik Tenaga Surya. Dari hasil rancang bangun Pembangkit listrik Sel Surya, didapatkan hasil untuk 1 sampai 4 buah panel surya 100 WP didapatkan tegangan pembangkitan 21,12 Volt dan daya pembangkitan 18,80 Watt rata-rata selama 7,8 jam. Sedangkan untuk Pembangkit Listrik Tenaga Mikro Hidro dihasilkan tegangan rata-rata 10,81 Volt dan daya pembangkitan 41,48 Watt selama 8 jam pemakaian.
\end{abstract}

Kata kunci: Pembangkit, Listrik hybrid, Sel surya dan Mikro hidro

\begin{abstract}
In the Department of Electrical Engineering,Islamic University "45" Bekasiuntil now does not have a laboratory of Renewable energy. In this research, a hybrid power plants have been designed by combined between hydroelectric power plants and solar power plants. From the design result of the Solar Cell Power Plant, obtained that for 1 to 4 pieces of $100 \mathrm{Wp}$ solar panel obtained the generation voltage of 21.12 volts generating power of 18.80 Watts on average time for 7.8 hours. Whereas for MHP the average voltage is 10.81 Volt and the generation power is 41.48 Watts for 8 hour of use.
\end{abstract}

Keywords: Power, Plant, Micro hydro, Solar, Cells

\section{PENDAHULUAN}

Jurusan Teknik Elektro Universitas Islam “45” Bekasi belum mempunyai peralatan laboratorium yang lengkap khususnya untuk laboratorium Teknik Pembangkitan listrik. Hal inilah yang melatar belakangi penelitian. Kebutuhan akan energi listrik saat ini terus meningkat dan sumber cadangan minyak bumi, gas, batu bara sebagai bahan bakar pembangkit energi listrik semakin menurun. Hampir semua sektor masyarakat menggunakan energi listrik maupun sumber-sumber energi tersebut. Konsumsi yang berlebihan dan ketergantungan pada salah satu sumber energi seperti pemakaian sumber bahan bakar minyak bumi sangat besar sekali, sementara itu untuk membentuk sumber energi minyak bumi dan gas membutuhkan waktu ratusan juta tahun.

Semakin menurunnya cadangan sumber bahan bakar minyak bumi, gas, dan batu bara sebagai bahan bakar pembangkit listrik serta semakin meningkatnya konsumsi energi membuat para ahli memikirkan untuk mencari sumber-sumber energi alternatif dan menggali serta menciptakan teknologi baru yang dapat menggantikan minyak bumi, gas, batu bara dan lainnya sebagai bahan bakar pembangkit listrik.

Pemanfaatan energi matahari dan air sebagai sumber energi alternatif pembangkit energi listrik merupakan terobosan yang sangat luar biasa selain karena matahari adalah sumber energi yang sangat besar, juga pemanfaatan energi matahari tidak memberi dampak negatif terhadap lingkungan. Alat ini dinamakan solar cell berupa alat semikonduktor penghantar aliran listrik yang dapat menyerap energi panas matahari untuk menyuplai energi listrik. Pengelolaan sumber daya energi secara tepat kiranya akan dapat memberi kesejahteraan bagi masyarakat umum. 


\section{MATERI DAN METODE}

\subsection{Pembangkit Listrik Hybrid}

Pembangkit listrik hybrid adalah pembangkit listrik yang memanfaatkan lebih dari satu sumber energi, seperti Pembangkit Lisrik Tenaga Surya (tenaga matahari) dan Pembangkit Listrik Tenaga Mikro Hidro (tenaga air)

\subsection{Definisi Sel Surya}

Sel surya atau fotovoltaik dapat berupa alat semikonduktor penghantar aliran listrik yang dapat secara langsung mengubah energi surya menjadi bentuk tenaga listrik secara efisien. Efek fotovoltaik ini ditemukan oleh Becquerel pada tahun 1839, dimana Becquerel mendeteksi adanya tegangan foto ketika sinar matahari mengenai elektroda pada larutan elektrolit. Bahan ini terbuat dari silikon berkristal tunggal. Bahan ini sampai saat ini masih menduduki tampat paling atas dari urutan biaya pembuatan bila dibandingkan energi listrik yang diproduksi oleh pesawat konvensional.

\subsection{Jenis Panel Sel Surya}

Panel sel surya mengubah intensitas sinar matahari menjadi energi listrik. Panel sel surya menghasilkan arus yang digunakan untuk mengisi baterai. Panel sel surya terdiri dari :

\section{a. Photovoltaic}

Menghasilkan listrik dari intensitas cahaya, saat intensitas cahaya berkurang (berawan, hujan, mendung) arus listrik yang dihasilkan juga akan berkurang. Dengan menambah panel sel surya (memperluas) berarti menambah konversi tenaga surya. Umumnya panel sel surya dengan ukuran tertentu memberikan hasil tertentu pula. Contohnya ukuran a $\mathrm{cm} \mathrm{x} \mathrm{b} \mathrm{cm} \mathrm{menghasilkan} \mathrm{listrik} \mathrm{DC}$ (Direct Current) sebesar x Watt per hour.

\section{b. Polikristal (Poly-crystalline)}

Merupakan panel surya yang memiliki susunan kristal acak. Type Polikristal memerlukan luas permukaan yang lebih besar dibandingkan dengan jenis monokristal untuk menghasilkan daya listrik yang sama, akan tetapi dapat menghasilkan listrik pada saat mendung.

\section{c. Monokristal (Mono-crystalline)}

Merupakan panel yang paling efisien, menghasilkan daya listrik persatuan luas yang paling tinggi. Memiliki efisiensi sampai dengan $15 \%$. Kelemahan dari panel jenis ini adalah tidak akan berfungsi baik ditempat yangcahaya mataharinya kurang (teduh), efisiensinya akan turun drastis dalam cuaca berawan. Skema instalasi Pembangkit Liatrik Tenaga Surya disajikan pada Gambar 1 dan Gambar 2.

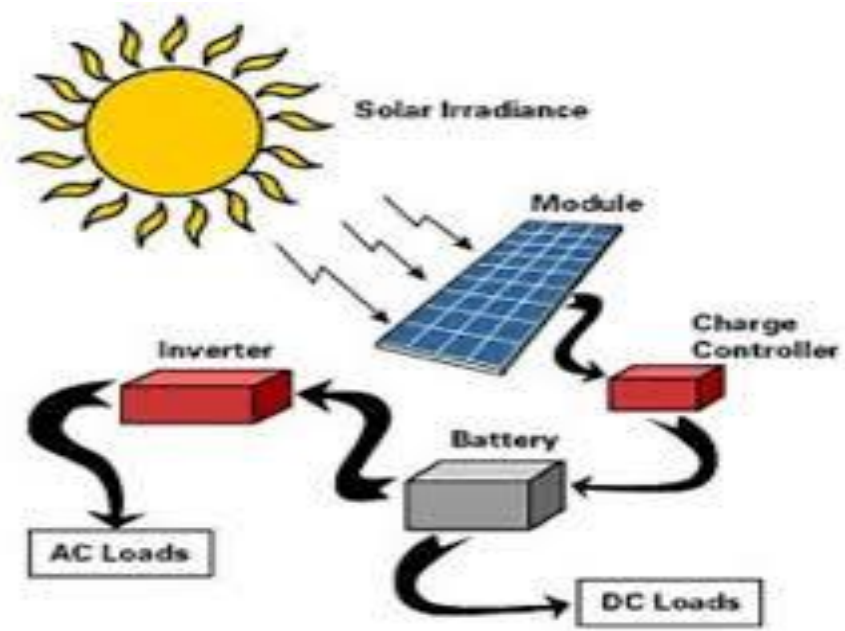

Gambar 1. Skema Instalasi Pembangkit Liatrik Tenaga Surya 


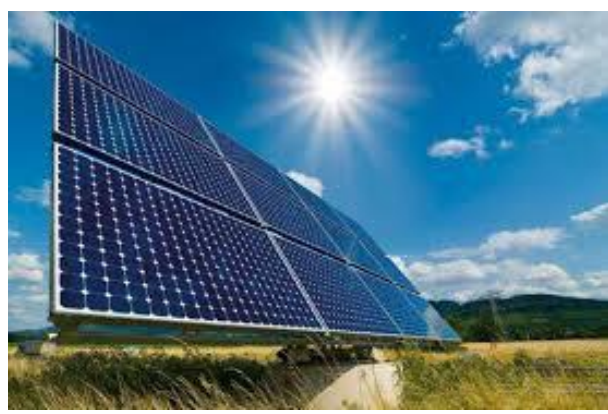

Gambar 2. Panel Sel Surya

Suatu kristal silikon tunggal photovoltaic dengan luas permukaan $100 \mathrm{~cm}^{2}$ akan menghasilkan sekitar 1,5 W dengan tegangan sekitar $0,5 \mathrm{~V}$ tegangan searah (0,5 V-DC) dan arus sekitar $2 \mathrm{~A}$ di bawah cahaya matahari dengan panas penuh (intensitas sekitar1000W/m²). Karakteristik $\mathrm{Sel}$ Photovoltaic disajikan pada Gambar 3.

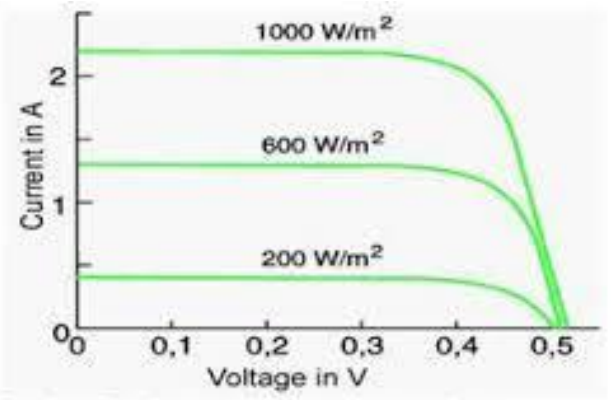

Gambar 3. Karakteristik Sel Photovoltaic

\subsection{Prinsip Kerja Sel Surya}

Prinsip kerja sel surya silikon adalah berdasarkan konsep semikonduktor p-n junction. Sel terdiri dari lapisan semikonduktor doping-n dan doping-p yang membentuk $\mathrm{p}-\mathrm{n}$ junction, lapisan antirefleksi, dan substrat logam sebagai tempat mengalirnya arus dari lapisan tipe-n (elektron dan tipe-p hole). Semikonduktor tipe-n didapat dengan mendoping silikon dengan unsur dari golongan $\mathrm{V}$ sehingga terdapat kelebihan elektron valensi dibanding atom sekitar.

Pada sisi lain semikonduktor tipe-p didapat dengan doping oleh golongan III sehingga elektron valensinya defisit satu dibanding atom sekitar. Ketika dua tipe material tersebut mengalami kontak maka kelebihan elektron dari tipe-n berdifusi pada tipe-p. Sehingga area doping-n akan bermuatan positif sedangkan area doping-p akan bermuatan negatif. Medan elektrik yang terjadi pada keduanya mendorong elektron kembali ke daerah-n dan hole ke daerah-p. Pada proses ini telah terbentuk p-n junction dengan menambahkan kontak logam pada area $\mathrm{p}$ dan $\mathrm{n}$ maka telah terbentuk dioda.

\subsection{Performansi Sel Surya}

Daya listrik yang dihasilkan sel surya ketika mendapat cahaya diperoleh dari kemampuan perangkat sel surya tersebut untuk memproduksi tegangan ketika diberi beban dan arus melalui beban pada waktu yang sama. Ketika sel dalam kodisi short circuit, arus maksimum atau arus short circuit (Isc) dihasilkan, sedangkan pada kondisi open circuit tidak ada arus yang dapat mengalir sehingga tegangannya maksimum. Disebut tegangan open-circuit. (Voc). Titik pada kurva I-V yang menghasilkan arus dan tegangan maksimum disebut titik daya maksimum (MPP).

\subsection{Komponen-komponen Pembangkit Listrik Tenaga Surya pada lampu penerangan}

Sistem pembangkit listrik tenaga surya (solar cell) untuk penerangan lampu mempunyai beberapa komponen diantaranya:

a. Solar modul (photovoltaics module)

Seperti yang sudah dibahas diatas, sel surya atau sel photovoltaic merupakan suatu alat yang dapat mengubah energi radiasi matahari secara langsung menjadi energi listrik. Pada dasarnya sel tersebut berjenis diode yang tersusun atas $\mathrm{P}-\mathrm{N}$ junction. Sel surya photovoltaic yang dibuat dari bahan semi konduktor dan diproses sedemikian rupa, dapat menghasilkan listrik arus searah (DC). Dalam penggunaannya, sel-sel surya itu dihubungkan satu sama lain, paralel atau seri, tergantung 
dari penggunaannya, guna menghasilkan daya dengan kombinasi tegangan dan arus yang dikehendaki.

b. Baterai

Baterai adalah alat penyimpan daya yang dihasilkan oleh panel surya yang tidak segera digunakan oleh beban. Daya yang disimpan dapat digunakan saat periode radiasi matahari rendah atau pada malam hari. Komponen baterai kadang-kadang dinamakan akumulator (accumulator). Baterai menyimpan listrik dalam bentuk daya kimia. Baterai yang paling biasa digunakan dalam aplikasi surya adalah baterai yang bebas pemeliharaan bertimbal asam (maintenance-free lead-acid batteries), yang juga dinamakan baterai recombinant atau VRLA (klep pengatur asam timbal atau valve regulated lead acid).

c. Inverter

Inverter adalah perangkat elektrik yang digunakan untuk mengubah arus listrik searah (DC) menjadi arus listrik bolak balik (AC). Inverter mengkonversi DC dari perangkat seperti baterai, panel surya/ solar cellmenjadi AC. Penggunaan inverter pada Pembangkit Listrik Tenaga Surya (PLTS) adalah untuk perangkat yang menggunakan arus listrik bolak-balik atau AC (AlternatingCurrent). Di antara yang perlu dipertimbangkan dalam pemilihaninverter adalah kapasitas beban dalam Watt.Usahakan memilih inverter yang beban kerjanya mendekati dengan beban yang hendak kita gunakan agar efisiensi kerjanya maksimal. Input DC 12 Volt atau 24 Volt, Sinewave ataupun square wave output $A C$

d. Beban (Load)

Beban adalah peralatan yang mengkonsumsi daya yang dihasilkan oleh sistem daya anda. Beban mungkin termasuk peralatan komunikasi nirkabel, lampu jalan, lampu penerangan rumah atau gedung, TV, radio, dan lain-lain. Adapun yang akan dibahas dalam penelitian sistem ini adalah lampu penerangan. Walaupun tidak mungkin secara persis memperhitungkan jumlah persis konsumsi peralatan, sangat penting untuk membuat perkiraan yang baik.

\section{e. Jenis Metode Pelaksanaan Sel Surya}

Pembangkit listrik energi surya dalam pelaksanaannya di bagi atas 4 metode, antara lain :

1) Dengan sistem fotovoltaik (photovoltaic),

2) Dengan sistem konversi fotoelektrokemis,

3) Dengan sistem penerima termal surya distribusi,

4) Dengan sistem penerima termal surya secara sentral.

\section{f. Sel Surya Charge Controller}

Sel surya charge controller adalah peralatan elektronik yang digunakan untuk mengatur arus searahyang ditambahkan ke baterai dan diambil dari baterai kebeban. Sel surya charge controller juga overcharging (kelebihan pengisian - karena baterai sudah 'penuh') dan kelebihan voltase dari panel surya, dimana akanmengurangi umur baterai. Sel surya charge controller menerapkan teknologi Pulse width modulation (PWM)untuk mengatur fungsi pengisian baterai danpembebasan arus dari baterai ke beban. Beberapa fungsi detail dari sel surya charge controller adalah sebagai berikut:

1) Mengatur arus untuk pengisian ke baterai,overcharging, overvoltage.

2) Mengatur arus yang dibebaskan/diambil dari baterai agar baterai tidak full discharge/over loading.

3) Monitoring temperatur baterai

\subsection{Pembangkit Listrik Mikro Hidro (PLTM)}

Untuk membuat Pembangkit Listrik Mikro Hidro ( PLTM), diperlukan komponen pendukung yaitu :

\section{a. Air Terjun}

Air terjun banyak sekali ditemui di negara kita Indonesia, sehingga merupakan sumber energi potensial yang sangat besar untuk kemudian dapat digunakan bagi kepentingan masyarakat. Klasifikasi air terjun dan kapasitas pembangkit hidro yang dihasilkan klasifikasi tinggi terjun dan kapasitas daya (Istilah Power Output Permen ESDM Tahun 2002) sebagai berikut:

1) Pico Hydro $<500 \mathrm{~W}$

2) Micro Hydro $500 \mathrm{~W}$ hingga $100 \mathrm{~kW}<1 \mathrm{MW}$

3) Mini Hydro $100 \mathrm{~kW}$ hingga $1 \mathrm{MW} 1 \mathrm{MW}-10 \mathrm{MW}$

4) Small Hydro $1 \mathrm{MW}$ hingga $10 \mathrm{MW}$

5) Full-scale (large) Hydro $>10 \mathrm{MW}$ 
Pembangkit listrik tenaga Mikro hidro pada prinsipnya memanfaatkan beda ketinggian dan jumlah debit air perdetik yang ada pada aliran air saluran irigasi, sungai atau air terjun. Aliran air ini akan memutar poros turbin sehingga menghasilkan energi mekanik. Energi ini selanjutnya menggerakkan generator dan menghasilkan listrik.

\section{b. Turbin}

Turbin adalah sebuah mesin berputar yang mengambil energi dari aliran fluida. Turbin sederhana memiliki satubagian yang bergerak, "asembli rotor blade/runner". Bagian-bagian turbin mikrohidro disajikan pada Gambar 4.

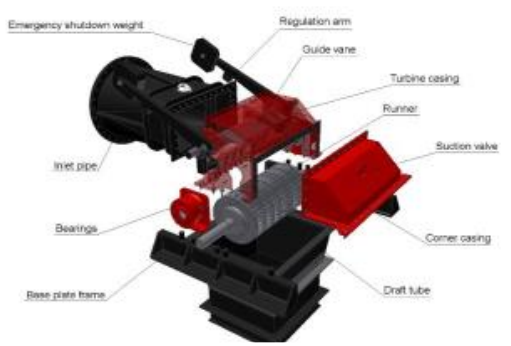

Gambar 4. Bagian-bagian dari turbin mikrohidro

Penjelasan tentang tingkat efisiensi, daya turbin dan generator adalah sebagai berikut :

\section{1) Tingkat Efisiensi Turbin}

Total efisiensi turbin crossflow mini dengan ketinggian yang kecil adalah $84 \%$ sepanjang aliran. Efisiensi maksimum dari turbin menengah dan besar dengan ketinggian yang besar, adalah $87 \%$. Kurva efiseine turbin disajikan pada Gambar 5.

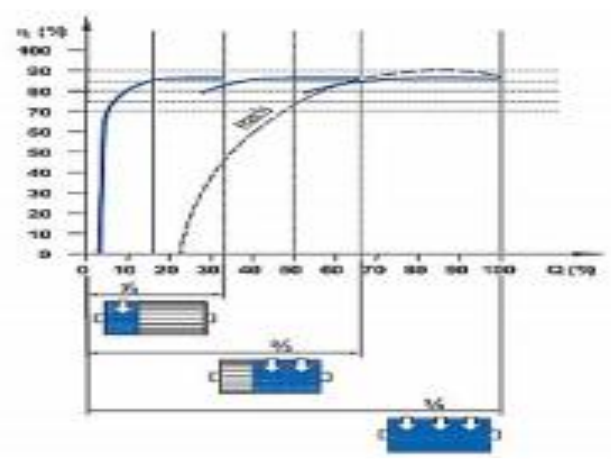

2) Daya Turbin

Gambar 5. KurvaEfisiensiTurbin Cross Flow

Besarnyadaya pada PLTMH pada keadaan debit maksimum adalah dirumuskan sebagai berikut :

$$
\mathrm{P}=\mathrm{g} \times \mathrm{Q} \times \mathrm{H} \times \eta
$$

\section{3) Generator}

Generator adalah alat untuk mengubah energi mekanik menjadi tenaga listrik.Tipe generator yang akan dipergunakan di PLTMH adalah generator sinkron horizontal shaft dengan putaran sebesar $1000 \mathrm{rpm}$. Pada generator sinkron Pembangkit Listrik Tenaga Mikro Hidro (PLTM) menggunakan kecepatan 1000 rpm sehingga kutup dalam generator berjumlah,

$$
\mathrm{P}=\frac{120 f}{N}
$$

Dimana:

$\mathrm{N}=$ Perputaran Generator $(\mathrm{rpm})$

$\mathrm{f}=$ Frekuensi $(\mathrm{Hz})$

$\mathrm{P}=$ Jumlahkutub 


\subsection{Perhitungan Besarnya Daya Keluaran Generator Pada PLTMH}

a. Perhitungan Debit Air: Debit merupakan salah satu parameter penting dalam perencanaan Pembangkit Listrik Tenaga Mikro Hidro. Ukuran debit air akan menentukan besarnya energi yang mampu dihasilkan.

b. Untuk menghitung debit air yang mengalir, digunakan rumus :

$$
\text { Debit }=\frac{\text { Volume Bejana }}{\text { Waktu untuk memenuhi bejana }}
$$

c. Tinggi Jatuh Air (Head): Untuk mendapatkan tinggijatuh air $(h)$ dilakukan pengukuran dengan menggunakan metode water-filled tube dimana diukur dari permukaan airatas pada nozzel hingga air menyentuh sudu pada runnerturbin.

d. Perhitungan Daya Input $\left(P_{i n}\right)$ : Setelah diperolehbesarnya debit dan head, maka dapat ditentukan besarnyadaya input $\left(\mathrm{P}_{\text {in }}\right)$ yang dihasilkan dengan rumus [3]:

Dimana :

$$
P_{\text {in }}=\rho . Q . g . h
$$

$\mathrm{P}_{\text {in }}=$ Daya input

$\mathrm{P}=$ Massa jenis air $\left(1000 \mathrm{~kg} / \mathrm{m}^{3}\right)$

$\mathrm{Q}=$ Debit air $\left(\mathrm{m}^{3} / \mathrm{s}\right)$

$\mathrm{G}=$ PercepatanGravitasi $\left(9,81 \mathrm{~m} / \mathrm{s}^{2}\right)$

$\mathrm{H}=$ Tinggi jatuh air $(\mathrm{m})$

e. Daya Output Generator (Pout): Daya output generator dihitung berdasarkan perkalian antara tegangan dan arus yang diukur menggunakan alat yaitu multimeter. Secara matematis, daya output dirumuskan sebagai berikut [4]:

Dimana :

$$
\mathrm{P}_{\text {out }}=\text { V.I }
$$

$\mathrm{P}_{\text {out }}=$ Dayakeluar $($ Watt $)$

$\mathrm{V}$ = Tegangan (Volt)

$\mathrm{I}=$ Arus (Ampere)

f. Perhitungan Efisiensi Masing - Masing Turbin:Efisiensi dihitung dengan membagi daya yang keluar darigenerator dengan daya masuk, atau secara matematis dapat dirumuskan sebagai berikut [5]:

$$
\eta=\frac{P \text { out }}{P \text { in }}
$$

\subsection{Metode}

Pada tahun pertama penelitian adalah rancang bangun prototype pembangkit sel surya. Pada penelitian ini dilakukan tahapan-tahapan kerja secara sistematis dan kontinyu hingga tercipta hasil keluaran berupa alat media pembelajaran praktikum pembangkitan listrik sel surya. Adapun tahapan-tahapan penelitian sebagai berikut :
a. Survei lapangan
b. Persiapan alat dan bahan
c. Perancangan Pembangkit Listrik Tenaga Hidro
d. Pembuatan dan Perakitan Instalasi Pembangkit Sel surya (Tahun I)
e. Pembuatan dan Perakitan Pembangkit Listrik Mikro Hidro (Tahun II)
f. Pengujian unjuk kerja Pembangkit Sel surya dan Pembangkit Mikro Hidro
g. Membuat Laporan

Diagram alur penelitian alat media pembelajaran praktikum pembangkitan listrik sel surya disajikan pada Gambar 6. 


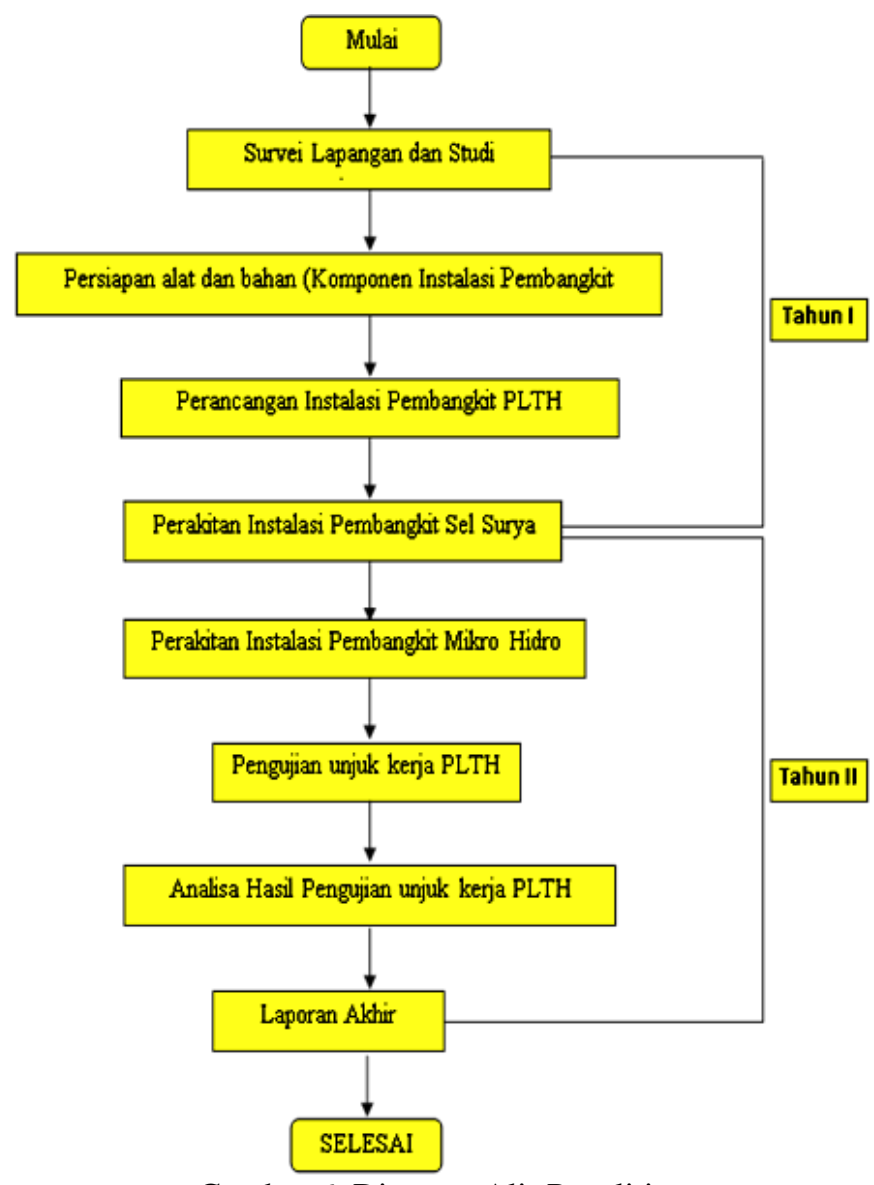

Gambar 6. Diagram Alir Penelitian

\section{HASIL DAN PEMBAHASAN}

\subsection{Hasil Pengujian Kinerja Alat}

Spesifikasi dan konstruksi alat pembangkit listrik sel surya yaitu: a. panel surya 100WP (4 Buah), b. tegangan keluaran 21,12, dan c. tegangan baterai $100 \mathrm{AH}$. Data hasil pengujian Pembangkit Listrik Tenaga Surya (PLTS) disajikan pada Tabel 1. Sedangkan kinerja alat disajikan pada Gambar 7.

Tabel 1. Data Hasil Pengujian Pembangkit Listrik Tenaga Surya (PLTS)

\begin{tabular}{cccccc}
\hline No. & Jumlah Panel & Teg.(Volt) & Isian & Waktu Pakai & Beban \\
\hline 1 & 1 Unit & & & 3,5 & 0,89 \\
2 & 2 Unit & \multirow{2}{*}{21.12} & \multirow{2}{*}{ 8 Jam } & 6,2 & 0,88 \\
3 & 3 Unit & & & 9,5 & 0,88 \\
4 & 4 Unit & & 12,35 & 0,87 \\
\hline \multicolumn{5}{c}{ Rata-rata daya pemakaian 18,80 Watt }
\end{tabular}




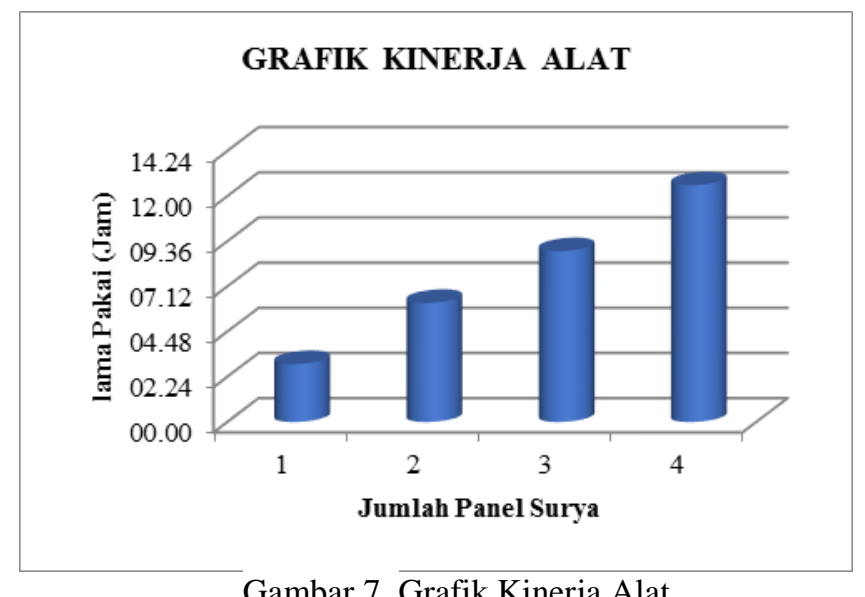

Gambar 7. Grafik Kinerja Alat.

\subsection{Hasil Pengujian Kinerja Pembangkit Listrik Mikro Hidro (PLTMH)}

Spesifikasi dan konstruksi Alat Pembangkit Listrik Mikro Hidro (PLTMH), yaitu: a. Model Turbin Pelton, b. Type pompa: Jet pump dengan daya input 125 watt, head pump m pada putaran 98 RPM, c. Daya generator 12 VA, putaran 98 RPM dan frekuensi Hz., dan d. Spesifiksi Runner (20 buah). Hasil pengujian Pembangkit Listrik Mikro Hidro (PLTMH) dengan durasi 8 jam disajikan pada Tabel 2.

Tabel 2. Data Hasil Pengujian Pembangkit Listrik Mikro Hidro (PLTMH) durasi 8 Jam

\begin{tabular}{cccc}
\hline No. & $\begin{array}{c}\text { Tegangan } \\
\text { (Volt) }\end{array}$ & $\begin{array}{c}\text { Kecepatan } \\
\text { (RPM) }\end{array}$ & $\begin{array}{c}\text { Daya } \\
\text { (Watt) }\end{array}$ \\
\hline 1 & 9,01 & 120 & 34,5 \\
2 & 9,05 & 135 & 36,5 \\
3 & 11,06 & 185 & 44,6 \\
4 & 11,08 & 200 & 44,6 \\
5 & 11,02 & 170 & 42,5 \\
6 & 12,01 & 210 & 46,8 \\
7 & 11,08 & 200 & 44,1 \\
8 & 10,09 & 150 & 42,9 \\
9 & 9,03 & 130 & 36,7 \\
\hline \multicolumn{4}{c}{}
\end{tabular}

\section{KESIMPULAN}

Dari rancang bangun Pembangkitlistrik Sel Surya, didapatkan hasil untuk 1 sampai 4 buah panel surya $100 \mathrm{WP}$ didapatkan tegangan pembangkitan sebesar 21,12 volt dandaya pembangkitan sebesar 18,80 Watt dengan rata-rata waktu selama 7,8 jam. Sedangkan untuk PLTMH dihasilkan tegangan rata-rata 10,81 Volt dan daya pembangkitan 41,48 Watt selama 8 jam pemakaian.

\section{REFERENSI}

1. Rislima Sitompul (2011), Teknologi Energi Terbarukan Yang Tepat Untuk Aplikasi di Masyarakat Pedesaan, Manual Pelatihan PNPM Mandiri (Hal 27-75).

2. Desri Akbari (2012), Pemanfaatan Teknologi Hibrid Berbasis Energi Surya Dan Angin Untuk Rumah Tangga, Makalah Ilmiah OSN Pertamina.

3. Firmansyah Putra Pratama, Mochamad Ashari dan Heri Suryoatmojo (2012), Sistem Pembangkit Listrik Hibrida PV-Diesel Microgrid Untuk Daerah Terisolasi Tanpa Menggunakan Media Penyimpan Energi, Jurnal Teknik Pomits Vol. 1, No. 1, (Hal 1-5). Teknik Elektro, Fakultas Teknologi Industri, Institut Teknologi Sepuluh Nopember (ITS)

4. Fulgensius (2016), Simulator Pembangkit Listrik Tenaga Piko HidroUntuk Modul Praktikum Di Laboratorium KonversiEnergi, Skripsi Jurusan Teknik Elektro Fakultas Teknik Universitas Tanjungpura.

5. Ari Wibawa Budi Santosa dan Imam Pujo Mulyatno (2014), Pemanfaatan Tenaga Angin Dan Surya Sebagai Alat Pembangkit Listrik Pada Bagan Perahu, Kapal, Vol. 11, No.3 (Hal.108-115). 
6. Ervan Hasan Harun, Jumiati Ilham dan lanto Mohamad Kamil Amali (2015), Potensi Hybrid Energy Di Kabupaten Bone Bolango Dan Kabupaten Gorontalo, Jurnal Setrum - Volume 4, No. 2, Issn : 2301-4652, Fakultas Teknik Universitas Sultan Ageng Tirtayasa

7. Ari Wibawa Budi Santosa \& Imam Pujo Mulyatno 2014, Pemanfaatan Tenaga Angin Dan Surya Sebagai Alat Pembangkit Listrik Pada Bagan Perahu, Jurnal Kapal, Vol. 11, No.3,Program studi TeknikPerkapalan,Teknik,Universitas Diponegoro,Indonesia

8. M. Rif'an dkk. 2012, Optimasi Pemanfaatan Energi Listrik Tenaga Matahari di Jurusan Teknik Elektro Universitas Brawijaya, Jurnal EECCIS Vol. 6, No. 1.

9. Achmad Bahri1 Dkk. (2017), Merancang Dan Mengimplementasi Modul Praktikum Pembangkit Listrik Tenaga Mikro Hidro Di Jurusan TeknikElektro Dan Komputer Universitas Udayana, Jurnal Teknologi Elektro, Vol. 16, No. 02. 